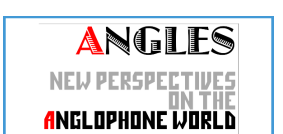

ANELOPHONE WORLI

\section{Angles}

New Perspectives on the Anglophone World

1 | 2015

Brevity is the soul of wit

\title{
Gender and Race Trouble: The Emperor Jones by The Wooster Group
}

\section{Emeline Jouve}

\section{(2) OpenEdition}

1 Journals

\section{Electronic version}

URL: https://journals.openedition.org/angles/2176

DOI: 10.4000/angles.2176

ISSN: 2274-2042

\section{Publisher}

Société des Anglicistes de l'Enseignement Supérieur

\section{Electronic reference}

Emeline Jouve, "Gender and Race Trouble: The Emperor Jones by The Wooster Group", Angles [Online], 1 | 2015, Online since 01 November 2015, connection on 06 June 2022. URL: http:// journals.openedition.org/angles/2176 ; DOI: https://doi.org/10.4000/angles.2176

This text was automatically generated on 6 June 2022.

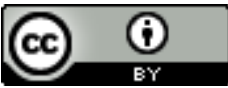

Angles est mise à disposition selon les termes de la Licence Creative Commons Attribution 4.0 International. 


\title{
Gender and Race Trouble: The Emperor Jones by The Wooster Group
}

\author{
Emeline Jouve
}

Figure 1: Charles Gilpin in The Emperor Jones (1920)

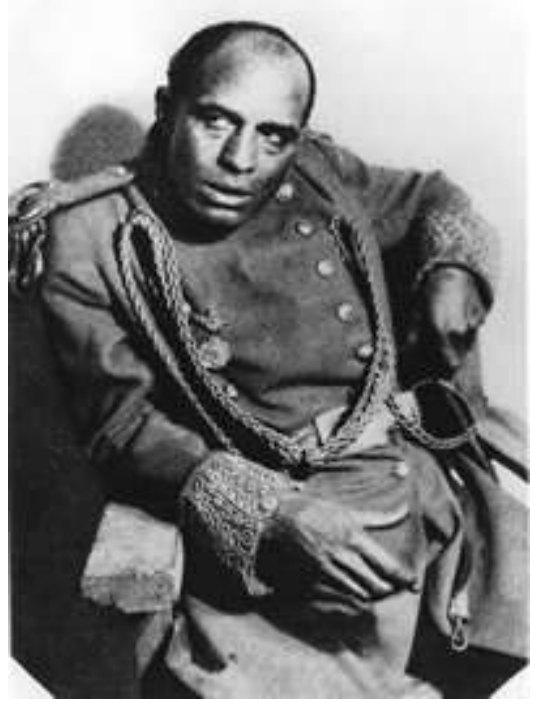

Source: ProvincetownPlayhouse.Com http://www.provincetownplayhouse.com/history.html 
Figure 2: Poster of The Wooster Group's The Emperor Jones

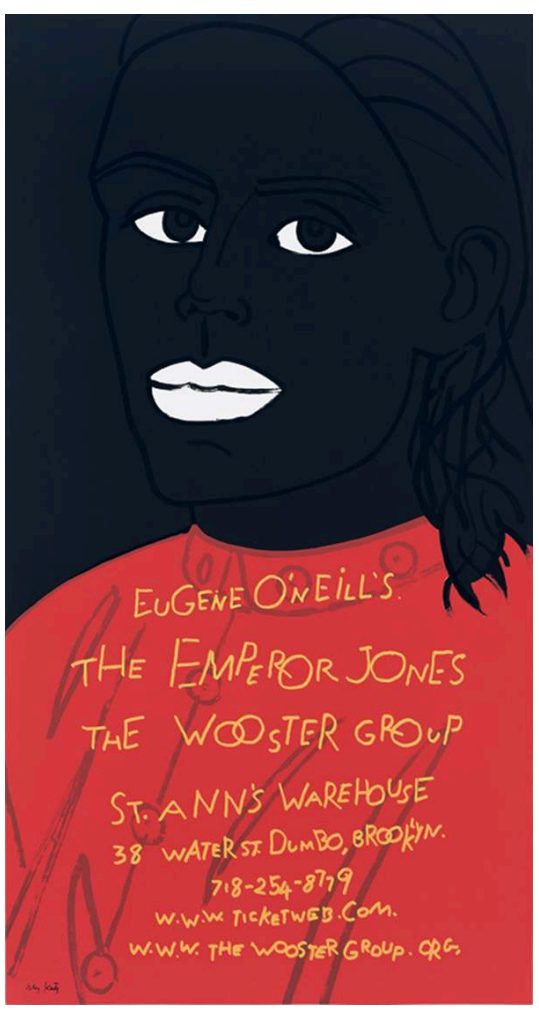

Print by Alex Katz. Source: The Wooster Group Website, http://thewoostergroup.org/posters

1 In Gender Trouble (1990) and later in Bodies That Matter (1993), philosopher Judith Butler argues that identity is not a biological phenomenon but is produced through "discourses." Identity is thus "performative" in that "it has no ontological status apart from the various acts which constitute its reality" (Gender Trouble 185). Although Butler focuses mainly on gender identity in her works, she reminds her readers in the introduction to Bodies That Matter that racial identity is "always a racial industry," that it is, like gender, the product of reiterated social practices or acts (Bodies xxvii). ${ }^{1}$ As a consequence, identity is constructed and defined by the cultural context in which one lives, a context which fixes the individual's social identity depending on predefined socio-historical criteria. Rejecting the postulate of stable selves, Butler calls on individuals to "trouble" the long-standing, stifling definitions of identities which trap them into specific categories. As long-standing "trouble-makers," The Wooster Group plays with fixed patterns and creates productions that are relevant to Butler's theory. Although the members of the iconoclastic American company deny any interest in theory and assert in interviews that they are just "making art," I argue in this paper that Butler's premise on the performative nature of identity offers valuable insights into The Wooster Group's works and, in particular, into their 1993 revival of Eugene O'Neill's most controversial play, The Emperor Jones, first performed in 1920 by the Provincetown Players. ${ }^{2}$ This play in eight scenes dramatizes the attempted escape of African-American-cum-island dictator Brutus Jones after his subjects have rebelled against him. Jones's spatial journey through the forest becomes a psychological journey of "racial" memory as the former slave recalls scenes from his early life, from the time before he had established himself as Emperor of an island in the West Indies. 
2 Starring OBIE-Award winning white actress Kate Valk as a black-faced Brutus Jones, The Wooster Group's production “troubles" the traditional configurations of both gender and race. Elizabeth LeCompte's company questions the playwright's construction of racial and gender identity. Butler believes that to free individuals from the yoke of norms it is necessary to overturn the power of the sign, of the symbolic. I will demonstrate in this essay's second part that The Wooster Group's staging proves symbolically subversive as it plays with the codes of representation to create new fluid, polymorphic categories that shed light on the artificiality of the conventional binary system opposing the masculine to the feminine and Whites to Blacks. Yet, one may wonder to what extent The Wooster Group succeeded in displacing the "strict lines [that are] drawn between the performance and life", overcoming another type of binary system which is paradoxically that of theatre itself as it confronts the imaginary with reality, i.e. the stage with the audience (Butler "Performative Acts" 278).

This media file cannot be displayed. Please refer to the online document http:// journals.openedition.org/angles/2176

\section{From Construction to Deconstruction}

\section{Construction: Eugene O'Neill's The Emperor Jones}

Figure 3: The Emperor Jones by The Provincetown Players (1920)

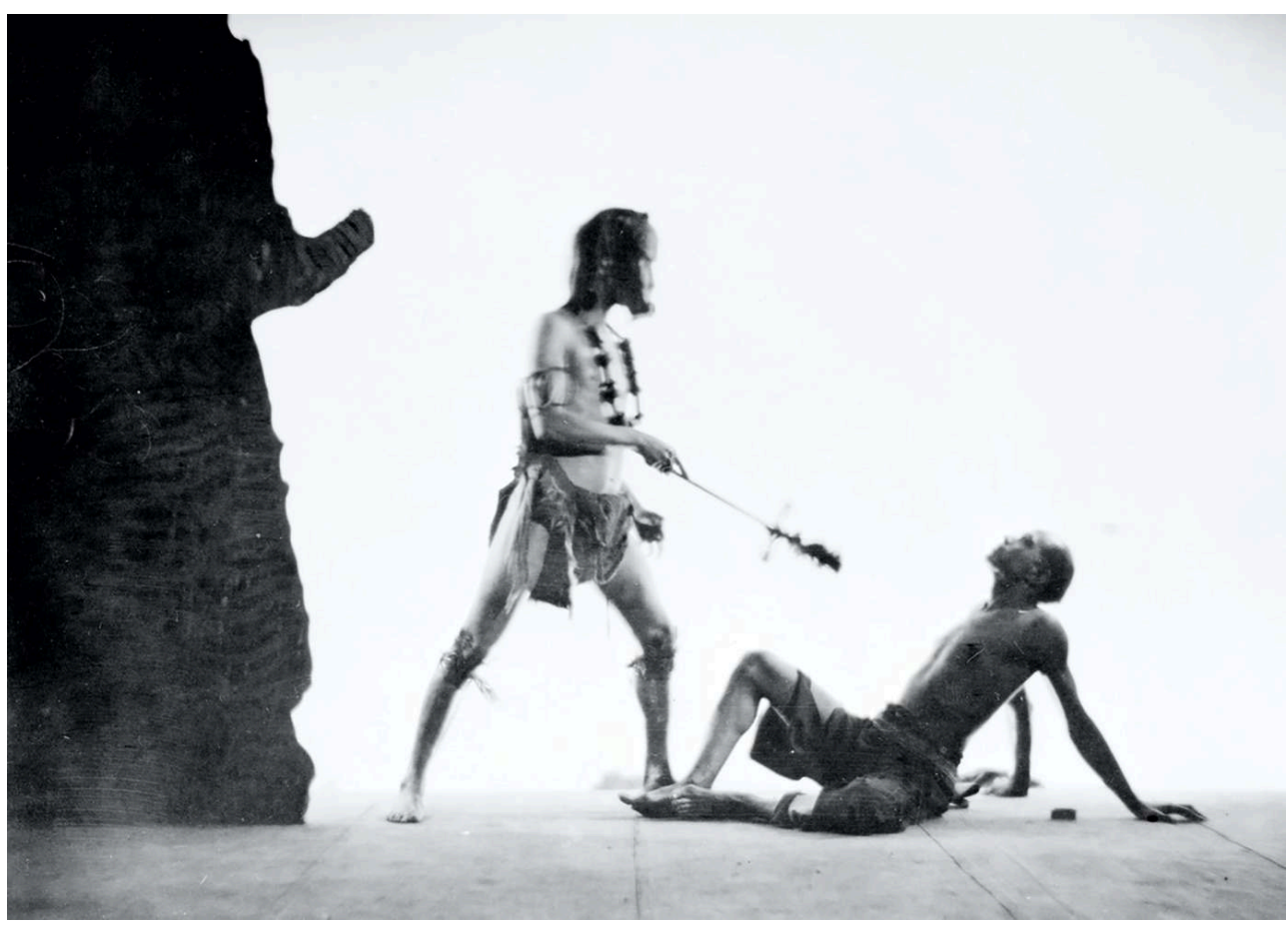

Credit: The Beinecke Rare Book and Manuscript Library. Source: https://www.pbs.org/wgbh/ americanexperience/features/oneill-gallery-performances-and-reviews-oneill-plays/.

Hailed as the "Father of the Modern American Theatre," Eugene O'Neill's dramatic progeny were not very diverse in terms of gender. As Judith E. Barlow asserts, the playwright "created a world populated primarily by men" (164). In The Emperor Jones, 
for example, O'Neill immerses his readers in an all male-world. Apart from the character of The old Native Woman, who has no other function than setting the context of the rebellion at the opening of the play, all the characters are men: "BRUTUS JONES, Emperor; HENRY SMITHERS, a Cockney trader; LEM, a Native Chief; SOLDIERS, Adherents of Lem" (O'Neill 3). Unsurprisingly, the play deals with themes that are traditionally associated with masculinity, such as the issues of domination and honor as well as with the anxiety of losing power. The Old Native Woman appears merely as a subordinate figure because she embodies fear and submission and acts as a foil for the other characters present in Scene 1. From the start of the play, she helps to establish the supremacy of the male characters including Smithers and Jones whom she significantly refers to as the "Great Father" (O'Neill 7). The woman's brief appearance on stage before leaving the floor to the male characters helps to establish a contrast between presence and absence, visibility and invisibility, an opposition which is reminiscent of the patriarchal binary system that posits men at the center and women on the margins. By introducing the audience to a world where men rule and where women have no other part to play than to serve men, O'Neill's The Emperor Jones offers from the outset a conservative vision of the relationships between the sexes. Furthermore, the issue of masculinity in the play is inextricably linked to that of race as all the male characters are black, with the sole exception of the British trader.

The play is considered as a landmark in the history of African-American acting since The Provincetown Players was the first white company featuring a black actor in a leading role (Figures 1 and 3). The black artist O'Neill entrusted with the part of Brutus Jones was Charles Gilpin, who, "by the time he took on the role of Emperor Jones was a veteran of minstrel shows" (Aberjhani and West 102). Although it would be too reductive to label Gilpin a "minstrel show actor", since he also played in Tom Shows and even played a white character in the 1915 production of Dion Boucicault's The Octoroon, most of his early successes were indeed on the minstrelsy stage (Salzman, David and West, 1110). Prior to the 1920s, few black actors took part in productions by white directors and most were confined to the part of the minstrel "nigger" which mostly implied "caricaturing their physical characteristics and lampooning their intelligence" (McArthur 51). Even though O'Neill has been praised by scholars for his momentous decision to cast a black actor, Barry B. Witham asserts that Jasper Deeter, who played the part of Smithers in the original production, had, in fact, to convince the playwright not to choose a white actor for the part of Brutus:

O'Neill's preference for a black actor has been widely documented, but Deeter claimed repeatedly that he lobbied for Gilpin rather than a more seasoned white actor-Charles Ellis-who would do the demanding role in blackface as was the custom. (Witham 29)

5 As Aoife Monks observes, the casting O'Neill finally agreed on was considered "radically progressive in an era of widespread black-face minstrel practice on the stage" (Monks 540). However, O'Neill did not totally manage to come to terms with the stereotypes of blackness conveyed in minstrelsy. Contrary to the expressionistic scenes that follow, the first scene of the play is realistic in style and supposedly offers a "realist" depiction of Brutus, only the playwright paradoxically does not introduce the readers to a realistic, true-to-life character but rather to a "type" since, for example, the protagonist is said to have "typically negroid" features (O'Neill 8). For many scholars, including Matthew H. Wikander, Brutus Jones appears as what was once referred to as a "Minstrel nigger": "In The Emperor Jones, the stage directions abound in stereotypes 
('Jones's eyes begin to roll wildly. He stutters [...]') and the dialect is reminiscent of the minstrel show" (Wikander 225). This interpretation cannot be deemed anachronistic: in the 1920s, black commentators criticized O'Neill's play because it seemed to "portray the worst traits of the bad elements of both races," a view deplored by AfricanAmerican scholar and activist W.E.B. Du Bois who applauded the dramatist for managing to go beyond the "almost universal misinterpretation" of the AfricanAmerican ("The Negro and the American Stage" 228).

Scholars have been divided over the interpretations of O'Neill's intentions behind his dramatic portrayals of African-Americans, as Edward L. Shaughnessy reminds the readers of "O'Neill's African and Irish-Americans: stereotypes or faithful realism?" (149). For Robert Károly Sarlós, one of the first historians of the Provincetown Players, The Emperor Jones does not deal with race but, rather, with "the blatant duality of human nature" (124). Joel Pfister questions whether the playwright created Black characters the audience would sympathize with or whether he extended "the stereotypes [...] that inhabited the cultural swamp of [his] literary imagination" (132). Margaret Loftus Ranald's view is less nuanced: she believes that "The Emperor Jones presents serious difficulties because of its racist overtones" (207).

Politically, Eugene O'Neill had no agenda regarding civil rights. As Gwenola Le Bastard writes, if the playwright "contributed to the integration of black actors within the American theatre and of the black community within American society, [he] made no direct political claim" (\$13). One may believe, as John Patrick Diggins contends, that O'Neill felt compassion for people of African descent but that this did not prevent him from inheriting the prejudices of the white society to which he belonged. Although O'Neill declared in 1946 that Charles Gilpin was the only actor who could "carry out every notion of a character [he] had in mind," O'Neill seemed, in the words of Wikander, to "have forgotten his dispute with Gilpin in 1920" when he learned that the actor, "suddenly finicky about using the work nigger (called for in the script), was rewriting the role." The playwright was even reported to have threatened the actor: "If I ever catch you rewriting my lines again, you black bastard, I'm going to beat you up" (qtd. in Wikander 224-225). O'Neill's attitude towards Gilpin may be read as evidence that the writer had not only to assert his authorial power but also his social authority over the black actor who, it should be said, was suffering from alcoholism, a problem that hampered his acting skills and infuriated the playwright. The white dramatist's decision to give center stage to black protagonists at a time when segregation reigned supreme was undeniably a step forward as it shed light on racial issues. However, since the political motivations of the artist were unclear, the political scope of the play was limited.

Deconstruction: Eugene O'Neill's The Emperor Jones by The Wooster Group 
Figure 4: Scott Shepherd, Kate Valk and Ari Fliakos in The Wooster Group's The Emperor Jones

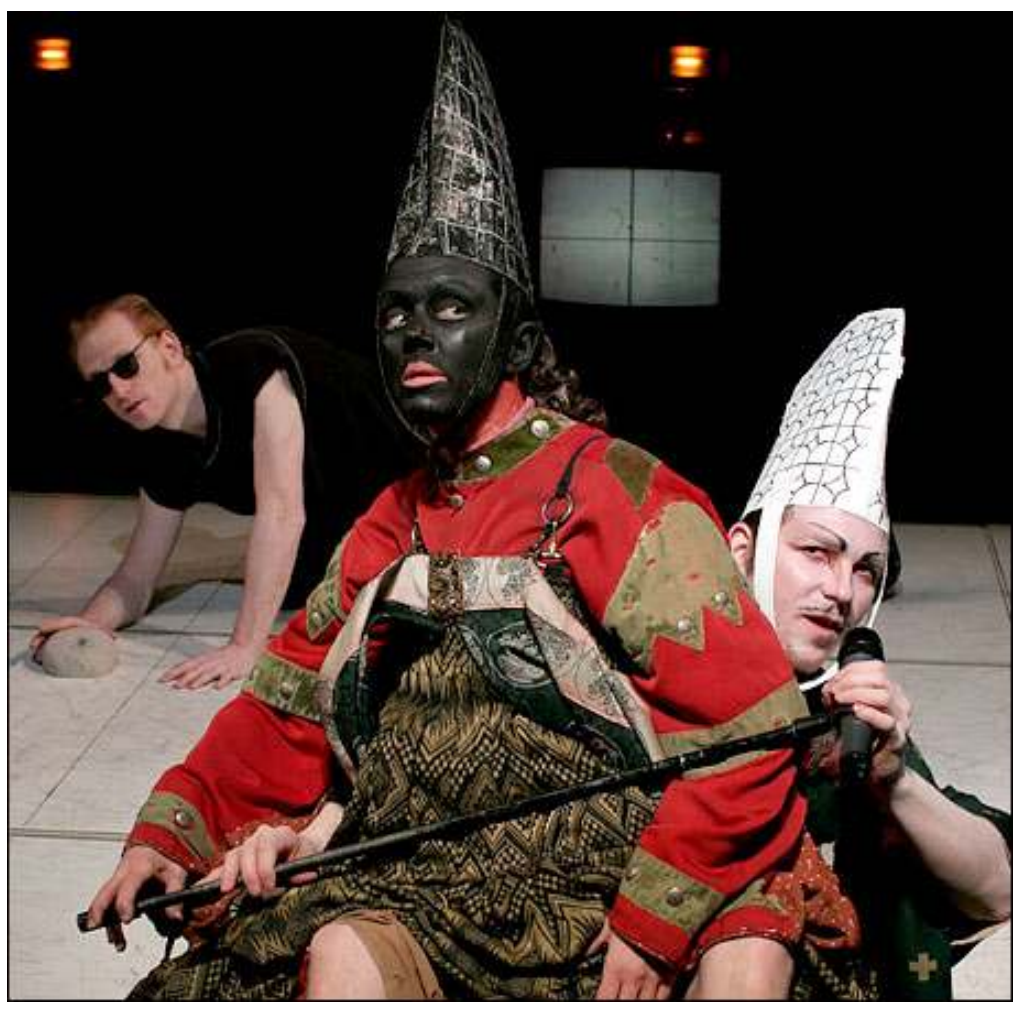

Photo by Paula Court. Source: https://www.nytimes.com/2006/03/14/theater/reviews/an-emperorwho-tops-what-oneill-imagined.html

The Wooster Group introduces their works as "part of the radical post-modern experiments of the time" (The Wooster Group, Facebook). As a postmodernist theatre company, The Wooster Group deconstructs theatre in order to stress its "artificiality," as Andrew Quick writes in The Wooster Group. Work Book (8). Contrary to O'Neill's expressionist experimentations, which attempt to reinforce the power of illusion, The Wooster Group's postmodern aesthetics breaks the theatrical illusion by "selfconsciously and systematically draw[ing] attention to its status as an artifact" (Waugh 2). In their production of The Emperor Jones, the tacky plastic palm trees on the boxing ring-like stage, which ostentatiously establish the fakeness of the set, or the presence of visible cables and backstage equipment which lays bare the fabric of the theatre, constantly remind the audience that they are watching a fiction. The Wooster Group's self-reflexivity also stems from the intermediality of a performance that mixes theatre, cinema, dance and music.

9 The metafictional nature of the performance is also conveyed by The Wooster Group's staging of the agents or "actors" of the creative process. The Emperor Jones starred three performers: Black-faced Kate Valk playing Brutus, Ari Fliakos and Scott Shepherd who alternated in playing Smithers and the Stage-Assistant. ${ }^{3}$ Valk, Fliakos and Shepherd are introduced as performers, playing fictional parts: Valk's mask-like black face, her cross-race and gender performance as well as Valk and Fliakos's Kabuki costumes (Figure 4), all work as "emblems of the actor's impersonation in the American Minstrel tradition and the classical Japanese tradition" and as such identified Kate Valk and Ari Fliakos as actors (Jouve). Additionally, the blend of "Asian-African fusion" blurs the location of the plot and disorients the spectators (Frank). Moreover, throughout The 
Wooster Group's production, the Stage-Assistant is present and the performance stresses his function as an off-stage figure participating in the creation of the show. He comes and goes during the performances and his backstage activities are visible because there is no curtain between the wings and the ring-like stage. The portrayal of Smithers fulfills multi-metatheatrical functions: introduced by the company as a fictive character impersonated by an actor, the Cockney trader also embodies the figures of the stage-director and of the playwright.

The character of Smithers was staged as a figure of authority. Physically absent from the stage at the beginning of the first scene, the white trader was however "technologically" present on the TV screen; he could also be seen off-stage, speaking his lines into a microphone. Jones turned his back to both the technological and the real off-stage Smithers as if the emperor was interacting with a voice only. This presence-absence strategy conveyed the impression that, from the start, Smithers was both literally and figuratively "behind" Jones, that this character, who can be seen as the narrative catalyst of Brutus's doom, stood as a voice-spirit triggering Jones's actions and thus controlling him. Smither's control over Jones was akin to that of the stage-director or of the author over her or his actors or characters. Smither's made-up moustache bore a striking resemblance to Eugene O'Neill's. This "metatextual" echo established Jones as "the representational creation of [O'Neill], the seemingly 'absent' playwright but the true arbiter of Jones's fate." (Jouve)

The implied presence of O'Neill playing on stage suggests that The Wooster Group's purpose was to explore The Emperor Jones as the product of the playwright's subjectivity and to introduce Brutus Jones as an artifact created by O'Neill.

11 The Emperor Jones marked a turning point in LeCompte's career since "it was the first time the Group had presented a play under its original title, largely uncut and unaltered textually, and without the interpolation of any other scripted text" (Bechtel 128). In the group's previous works, which corresponded to Hans-Thies Lehmann's definition of "postdramatic theatre," the text was considered "as a 'material' of the scenic creation, not as its master" (Lehmann 17). In The Emperor Jones, however, the text plays a central role: the company explores the very construction of the text to deconstruct the playwright's subjective interpretation of the theme of identity in his play. By reviving the minstrel tradition and casting a female Brutus, Kate Valk, who "sounds like a large black man, snarling, elongating words, shifting the pitch and tempo of her lines, almost singing the phrases," The Wooster Group posits O'Neill's subjective interpretation of identity as stereotypical and exposes its white and malecentered biases (Frank).

\section{The Power of the Symbolic: Repetition and Subversion}

\section{Eugene O'Neill and Symbolic Reiteration}

O'Neill's Brutus Jones, as staged in The Wooster Group's production, can be seen as an illustration of what Judith Butler denounces as the fictitious dimension of identity in contemporary Western societies which value the "performative" over "the ontological" (Gender Trouble 185). The individual, according to the philosopher, is thus conditioned to reproduce a set of attitudes to match different social expectations corresponding to the racial and gender categories to which one belongs. Initially introduced as a realistic character in the first realistic scene of the play, Brutus should consequently be the 
representative of objective reality-the representation of objective reality being central to realism-while he is, in fact, a representative of O'Neill's subjective reality, which somewhat mirrors the conventional segregationist social mechanisms at play in the United States at the beginning of the twentieth century.

When Charles Gilpin questioned the use of the word "nigger" in O'Neill's script, he pointed out the power of the symbolic, of the signifier over the signified, a distinction that Butler later makes in Gender Trouble and Bodies That Matter. For Butler, identityand thus gender and race identities-are abstract concepts which result from symbolic repetitions, that is, from "the repeated [naming and] stylization of the body, a seat of repeated acts within a highly rigid regulatory frame that congeal over time to produce the appearance of substance, of a natural sort of being" (Gender Trouble 33). O'Neill's white patriarchal society provides a "rigid regulatory frame" by which the black individual must abide. By using the word "nigger" in his play and then, in a fit of anger, by calling his actor a "black bastard," O'Neill perpetrated the set frame of what Butler calls the "racial industry," that is, preconceived social visions of blackness. By attempting to get away from the prejudiced set patterns of the minstrel show and having a black actor on stage while paradoxically reproducing these very same patterns through stilted “typically negroid" characterization, O'Neill unintentionally demonstrated that he was trapped by the reiterative power of social discourses.

Very few scholars have discussed the presence of black-faced actors in O'Neill's production of The Emperor Jones, focusing instead their attentions on Gilpin, who not only became "the first Negro ever cast by a white American company for a major role," but also "the first black actor to achieve Broadway stardom in a non-musical drama," since The Emperor Jones was brought to Broadway after its initial success on the stage of the Provincetown Players (Sheaffer 32, Krasner 96). The parts of the Native Chief, Lem, and of The Native Woman were performed by black-faced white actors, respectively Charles Ellis-who had initially been cast as Brutus Jones, according to Jasper Deeterand Christina Ell. Both Ellis and Ell were reported to have "blackened their bodies as required" by their parts (Smith 207). It can be argued that, from a formal perspective, black-facing is to race what drag is to gender, that is a "reidealization of hyperbolic [...] norms" (Bodies that Matter 85): by blackening their faces, the white actors of The Provincetown Players reiterated the conventions of the minstrel show which in itself was an exaggerated reiteration of the way black people were perceived in 1920s America; the blackened bodies of the white actors maintained the "norms that govern the intelligibility" of race (Bodies that Matter 96$).^{4}$

"The omnipotence of whiteness as the social 'author' of identity is underscored in [O'Neill's] text by Jones's eagerness to pass as white, which stands as the norm, the normality that any free powerful man aspires to reach" (Jouve). In the character description, Brutus is described as being dressed like a white man in the American army:

He wears a light blue uniform coat, sprayed with brass buttons, heavy gold chevrons on his shoulders, gold braid on the collar, cuffs, etc. His pants are bright red with a light blue stripe down the side. Patent leather laced boots with brass spurs, and a belt with a long-barreled, pearl-handled revolver in a holster complete his makeup. (8)

The term "makeup" posits Brutus's outfit as "a kind of parody of white clothing, a garish version of a western military outfit" (Monks 546). Brutus, like any individual according to Butler's theory, is deprived of any agency, he is not free to choose which 
identity to enact, although he believes he can. The tragedy of the protagonist's life is indeed to think that by changing his costume, by dressing like a white man, he can change the script of his life, a belief that leads him to his death. In scene 1, for example, the protagonist claims that he has learned the lessons of life by "listenin' to de white quality talk": Brutus Jones is the product of white culture whose "talk[s]," or discourses, he blindly reproduces at his own expense (O'Neill 12). Rather than subverting the dominant racial discourse, he reiterates the symbolic and reinforces the racial framework which equates power with the whiteness that he tries to imitate. If O'Neill's protagonist can change his surface costume, i.e. his military outfit, he cannot change the ultimate costume he is made to wear: his black body.

To explain the performative dimension of the body, Butler introduces it as a physical signifier prior to the linguistic signifier which influences actions:

The body posited as prior to the sign, is always posited or signified as prior. This signification produces an effect of its own procedure the very body that it nevertheless and simultaneously claims to discover as that which precedes its own action. If the body signified as prior to signification is an effect of signification, then the mimetic or representational status of language, which claims that signs follow bodies as their necessary mirrors, is not mimetic at all. On the contrary, it is productive, constitutive, one might even argue performative, inasmuch as this signifying act delimits and contours the body that it then claims to find prior to any and all definitions [emphases in the original]. (Butler, Bodies that Matter 6)

Brutus cannot escape the fate of matter. As the fall of the protagonist looms near, his body becomes increasingly visible. In Scene 4, Jones rids himself of the costumes of the white master which he now tellingly compares to a "strait jacket"-“I'm meltin' wid heat! Runnin' an' runnin' and runnin'! Damm dis heah coat! Like a strait jacked! [He tears off his coat and flings it away from him, revealing himself stripped to the waist]"-, but he cannot escape from social oppression. Instead, he is reduced to the original, social status which his skin color assigns him in American history: that of a slave (Scene 5), then that of a savage whom the white God cannot save (Scene 7) (O'Neill 33). In O'Neill's The Emperor Jones, bodies are symbolic of the conventional social order as illustrated by the depreciation of the black body and the invisibility of the female body.

\section{The Wooster Group and the Crisis of the Symbolic}

While The Emperor Jones relegates women to the margins of both plot and society, The Wooster Group's staging of O'Neill's play questions this symbolic absence. At the opening of the performance, the stage is plunged in darkness and there are no signs of life except for a TV monitor with a scrambled screen which then reveals the face of the Old Native Woman played by Kate Valk. The Wooster Group introduces life as artificial: the natural body of the actor is replaced by a televised image. The physical absence of the female character on stage stresses the theme of women's absence in O'Neill's patriarchal society. In this production, the native woman is the only character who speaks in Scene 1, as the lines of her interlocutor are omitted. While Smithers's silence could be seen as the symbol of the female character's empowerment, it actually reinforces the impression of her submission to a looming superior entity. Since no one replies, her fears of retribution by the white trader and her Emperor appear as internalized alienating fears of male authority. The silence surrounding her lines elicits palpable tension, a sense of suffocating oppression. Female alienation is also conveyed by the TV monitor itself, as the woman appears trapped by the superficial frame of the 
video set. Just as The Wooster Group literalizes the metaphor of Jones's inability to escape his fate as a black man by pulling down a metallic structure which entraps the protagonist on the ring-like stage in Scene 7, they literalize the social metaphor of women's forced isolation in Scene 1. The issue of gender is complicated in this production by that of race by casting a female white lead to play the part of a black male, demonstrating that the problems of definitions of gender and racial identities are subject to similar mechanisms.

In "Brutus Jones 'n the 'Hood: The Provincetown Players, The Wooster Group, and the Theatrical History," Roger Bechtel examines the opening of the play and, focusing on the staging of race, argues that "from the outset of the performance, virtually every representation of race is in some way destabilized":

Perhaps the most exemplary instance of this is the opening image, the digitally negativized picture of the old native woman, which loses none of its disorienting effect when Valk's actual face is first illuminated. In fact, the effect is compounded, for the negative image does not serve as a relativizing erasure of the black makeup on Valk's face, but instead creates a racial hybrid that neither melds the two races nor privileges one over the other. Not only is the digital "whiteface" troubled by its black lips and eyes, but the dialect it speaks is clearly Afro-Caribbean. When we see the actual Valk in blackface, we understand that the screen image is a video distortion of a black face-or is it? (Bechtel 148-149)

Echoing the beginning of the play, the closing scene, in which the faces of Smithers and Lem-both played by Fliakos-appear on the TV monitor, also helps to destabilize the construction of racial identities as the black negative image of Fliako's face representing Lem and the positive image representing Smither call "into question the stability of racial origins" (Monks 556). Of course, the stability of racial, gender identity is also questioned by Valk's performance since, on screen, she represents a woman right before appearing, "live," wearing the blackface mask of the male minstrel as the male Emperor. This series of reversals challenges accepted patterns of gender and racial representations. The Wooster Group's use of videos, which often function as the reiteration of a previous image, can be interpreted as the staging of the Butlerian theory of symbolic repetition fostering social identities. The Wooster Group's repetition of normative patterns, which they subvert through technological and performative masking, creates hybrid bodies, both black and white, male and female that helps to destabilize conventional notions of race and gender.

Hybridity defines the very aesthetic of The Wooster Group's The Emperor Jones, an aesthetic which Aoife Monks defines in terms of "cross-dressing":

Cross-dressing can be immediately located in the Wooster Group's production, with Valk's gendered, raced, Orientalist, and mediated crossings on stage. Cross-dressing manifests itself in the production through a variety of masks: the make-up, costume, and vocal stylization, and the technological masks provided by the Wooster Group's famous use of television screens and microphones on the stage. (Monks 542)

23 As Cherise Smith, quoting Marjorie Garber, reminds us, "cross-dressing goes beyond the popular understanding of a man wearing woman's clothing and instead includes any type of crossing of identity boundaries, whether ethnic, class, religious, sexual or otherwise" (15). "One of the goals of the cross-dresser," Smith adds, "is to pass temporally as or for the assumed identity" (15). I would argue that, in The Wooster Group's production, "cross-dressing" is not an attempt to pass as an "other," to cross in the sense of to go beyond the boundaries of genders and races to impersonate a new 
social persona. The ensemble's "cross-dressing" is rather a constant criss-crossing of boundary lines that fosters hybrid figures. By playing with hybridity through such crisscrossing, the company provokes what Butler calls a "crisis in the symbolic." Focusing on the theme of the sexed body in her chapter "Gender is Burning" from Bodies that Matter, Butler writes:

The crisis in the symbolic understood as a crisis over what constitutes the limits of intelligibility, will register as a crisis in the name and in the morphological stability that the name is said to confer... The body which fails to submit to the law or occupies that law in a mode contrary to its dictate, thus loses its sure footing-its cultural gravity-in the symbolic and reappears in its imaginary tenuousness, its fictional direction. Such bodies contest the norms that govern the intelligibility of sex. (Butler, Bodies that Matter 96)

For Butler, American novelist Willa Cather is one of the few artists who manages to subvert the performative power of signs. "In Cather's fiction," she writes, "the name not only designates a gender uncertainty, but produces a crisis in the figuration of sexed morphology as well. [...] [I]n this sense, Cather's fiction can be read as the foundering and unraveling of the symbolic on its own possible demands" (97). Butler continues:

Cather cites the paternal law, but in places and ways that mobilize a subversion under the guise of loyalty. Names fail fully to gender the characters whose femininity and masculinity they are expected to secure. The name fails to sustain the identity of the body within the terms of cultural intelligibility; body parts disengage from any common center, pull away from each other, lead separate lives, become sites of phantasmatic investments that refuse to reduce to singular sexualities. (Butler, Bodies that Matter 97)

Like Cather, The Wooster Group cite the paternal law by staging O'Neill in their production and they subvert this law. The signifiers or the symbols that carry meaning, the costumes and the masks in the theatre, fail not only to gender the fictional figures but also to assign a racial identity to the characters whose bodies are staged as hybrid. The Wooster Group's staging disrupts the fixed patterns of social identity in which O'Neill's characters are trapped.

\section{The Wooster Group, Theatre and Resistance}

\section{Performance and Performativity}

In her article "Performative Acts and Gender Constitution: An Essay in Phenomenology and Feminist Theory," Judith Butler questions the power of theatre as a place of resistance. ${ }^{5}$ Because she considers performance to be the repetition of a preexisting model, she argues that artistic performances and performing arts are rarely subversive. The Wooster Group proves Butler wrong, however, in part at least, as we shall see. If on the level of the modes of representation the company manages to break away from repetitive patterns, we may wonder whether they actually manage to displace the "strict lines [that are] drawn between the performance and life" (Butler "Performative Acts" 278).

Butler asserts in an interview that "[w]hereas performance presupposes a preexisting subject, performativity contests the very notion of the subject" (Salih 56). Significantly, The Wooster Group's The Emperor Jones effectively illustrates this opposition between 
performance and performativity. Since its creation in 1975, the group led by Elizabeth LeCompte has been breaking away from the tradition of realistic theatre in which performance-the bringing to life on stage of a story, the enactment of a narrative-is a faithful physical translation of a text based on "preexisting" social patterns that it mimics. Rather than offering a realistic imitation of O'Neill's script, the troupe's performance subverts the repetition of the symbolic both through the visual construction of hybrid bodies and the confrontation of two levels of performativity. By textually citing the normative paternal law and playing on visual subversions through racial and gender cross-dressing, the company confronts two semiological systems: the visual sign, on the one hand, and the linguistic sign, on the other. The visual sign system, which is composed of the bodies of the actors, the costumes, the set, etc., contradicts the script, the linguistic sign system, or what Butler calls the "name." There is indeed an opposition between the text, which refers to a black man, for example, and its visual rendering, since the black man is represented on stage by a black-faced white woman. This opposition between the performativity of the written signs (the first level of performativity) and the performativity of the visual signs (the second level of performativity) suggests that the performance does not reproduce or repeat the first level of performativity but, on the contrary, fosters a new level of performativity.

The Wooster Group demonstrates that, as an art of performance, theatre has the power to resist the vicious circle of repetition as the performance does not repeat the preexisting script but has the power to subvert it and create new meanings. ${ }^{6}$ Through cross-dressing, the company enacts this resistance. Although parodic drag performance, according to Butler, maintains the dominant norms by "being used in the service of both the denaturalization and reidealization of hyperbolic [...] norms" and thus "further[s] a politics of despair," the hybrid, cross-dressed and criss-crossed performances in The Emperor Jones displaces the very norms "that enable representation itself" and thus promote a politics of change (Bodies 85, Gender Trouble 200, 203). "If identities were no longer fixed as the premises of a political syllogism, and politics no longer understood as a set of practices derived from the alleged interests that belong to a set of ready-made subjects," Butler writes, "a new configuration of politics would surely emerge from the ruins of the old" (Gender Trouble 203). I would like to argue that The Wooster Group does manage to create "a new configuration of politics," and that this emergence of new identity representation through the deconstruction of traditional forms typifies what Philip Auslander defines as "postmodernist political theatre," a "theatre of resistance that "investigate[s] the processes which control [given representations]' through the examination of iconography and the effects of mediatization on political imagings" (104). Politically challenging the modes of representation, we may wonder, however, whether The Wooster Group as a theatre company also manages to prove Butler wrong about their ability to challenge the traditional politics of configuration on the level of reception.

\section{Reception and Distantiation}

In terms of reception, physical and psychological distanciation are the tenets of The Wooster Group's approach. Although the company emerged from Richard Schechner's Performance Group, which has been highly influential in the troupe's approach to spectatorship, LeCompte departed from Schechner's "subjective theatre concentrat[ing] solely on "the psychology of perception"' to establish a more distanced 
relationship with her spectators (Innes 271). Among the troupe's different distancing strategies is the "the metaphor and the physical reality of the mask" (Quick 273). According to Andrew Quick, Kate Valk believes that "the mask can appear in many guises" and that "[i]t is most obvious in the use of blackface." One of the functions of the mask is that "it establishes a sense of distance between the performer and the audience, creating a barrier between a two-way process of potential psychological identification: the performer with the audience and the audience with the performer" (Quick 273). Distanciation is a principle of political theatre in the Brechtian tradition which encourages the spectators to disrupt empathetic identification and to react intellectually-rather than emotionally-to a production in order to question the dominant social order. If we go back to Butler's theory and views on theatre, we may question The Wooster Group's strategy which consists in maintaining a distance between the fiction that is being performed and the reality of the audience. ${ }^{8}$ If the production of The Emperor Jones does involve the spectators intellectually, it does not however directly engage them in the concrete process of identity reconstruction. In her essay, "Performative Acts and Gender Constitution: An Essay in Phenomenology and Feminist Theory," Butler writes:

Although the links between a theatrical and social role are complex and the distinctions not easily drawn [...], it seems clear that, although theatrical performances can meet with political censorship and scathing criticism, gender performances in non-theatrical contexts are governed by more clearly punitive and regulatory social conventions. Indeed, the sight of a transvestite onstage can compel pleasure and applause while the sight of the same transvestite on the seat next to us on the bus can compel fear, rage, even violence. The conventions which mediate proximity and identification in these two instances are clearly quite different ... In the theatre, one can say, "this is just an act," and de-realize the act, make acting into something quite distinct from what is real. Because, in this distinction, one can maintain one's sense of reality in the face of this temporary challenge to our existing ontological assumptions about gender arrangements; the various conventions which announce that "this is a play" allows strict lines to be drawn between the performance and life. (Butler "Performative Acts and Gender Constitution" 278)

Contrary to Schechner's theatre in which the division between the worlds of the actors and that of the spectators is blurred, the spectators attending The Emperor Jones are never invited to cross the "strict lines [...] between the performance and life." LeCompte focuses on reforming the world of fiction and on empowering her "actors"the word is meaningful-who are entrusted with the "ethical" mission to reinvent forms of both racial and gender identities rather than creating a new reality "through a genuine social exchange between performer and spectator" as Schechner tried to do (Quick 274, 9). The "spectator's role, as [LeCompte] expresses in an interview with David Savran, is to witness events, rather than become an active or equivalent participant in their performance of them" (Quick 9). By establishing the spectators as "witnesses," LeCompte seems to minimize their power of agency: viewers are put in the position of "witnesses," that is, etymologically speaking, of those who "testify," "acknowledge" social injustices with regard to race and gender but who cannot become agents of change. As the company introduces the audience to new patterns of representation in The Emperor Jones, the spectator may regret that LeCompte did not go as far as to build bridges between the world of reconfiguration and the sphere of the real in order to encourage real concrete changes. Rather than a "theatre of resistance," which implies the attempt to initiate tangible social changes, The Wooster Group's The 
Emperor Jones can be defined as an "aesthetic of resistance," a phrase which appears more appropriate to account for the subversive nature of the reconfiguration of identity in the fictive world.

Although Butler minimizes artists' exposure to "political censorship and scathing criticism," both O'Neill and The Wooster Group took risks in staging their works (Butler "Performative Acts and Gender Constitution" 278). If the playwright's progressivism should be qualified, it is important to stress, as Bechtel does, that O'Neill was facing judicial prejudices by casting a black actor in the United States in the 1920s. By revisiting the minstrel tradition, The Wooster Group exposed themselves to criticism and funding cuts, as they did with their 1981 show Route $1 \& 9$ (The Last Act), "a radical revisioning of Thornton Wilder's Our Town" which featured "a mish-mash of popular past performance styles, including blackface minstrelsy and pornography, the combining of which caused controversy, protest, and the rescinding of forty per cent of the Group's funding from the New York State Council" (Monks 561). Although the use of blackface in The Emperor Jones may have seemed offensive to some, the production did not generate as much controversy as did Route $1 \& 9$. Bechtel argues that the different reception of The Emperor Jones may be explained by "the historical evolution of authorial license," as well as by the evolution in the way the group approached the minstrel tradition in the two works (160). Unlike with Route 1 \& 9, blackface was "explicitly introduced as a mask, both a theatrical and a social construction of blackness in The Emperor Jones" (Jouve). Indeed, contrary to their previous production in which the actors' whole bodies were blackened, in The Emperor Jones only Valk's face was made up in black-her neck, hands and arms remained white. Because of the integral blackening of the bodies, the black characters in Route $1 \& 9$ could be seen as "drags," to return to Butler, imitations of the blackface minstrel characters, an imitative strategy which exposed The Wooster Group to the ambivalence of the reiterative drag-like performance. The drag performance could be interpreted as a "reidealization" of the norms underpinning minstrelsy and thus be perceived by the detractors of the company as racist. In The Emperor Jones, however, The Wooster Group broke away from the traditional representation of the male minstrel character by adopting a crisscrossed, cross-dressed performance, and thus avoided the trap of the drag performance. This syncretism resulting from the gender/race combination but also the fusion of European, African and Asian theatrical aesthetics softened the potentially offensive effect of blackfacing alone on which Route 1 \& 9 centered. Contrary to the 1981 show, the relative absence of strong negative reactions to the use of blackfacing in The Emperor Jones may be accounted for by the gender reversal from a female performer to a male character. If men dressed up as women have proven to have a comic potential in the theatrical tradition in general but also in the minstrel tradition in particular, women representing men on stage reshape the interpretation of blackfacing as above ridicule. By explicitly deconstructing, rather than imitating, the racist male-centered minstrel pattern, LeCompte's troupe powerfully demonstrated in this production that identity is a construct, and that, in O'Neill's times-and perhaps in subsequent historical periods-, race and gender representations were stereotypical and offensive.

If The Wooster Group's The Emperor Jones does not challenge Butler's assumption that theatre can "break down [the] conventions that demarcate the imaginary from the real" by maintaining both spatial and psychological distance with the members of the audience, Elizabeth LeCompte's aesthetics of resistance engages in a reconfiguration of 
the codes of gender and race identity and as such "troubles" the long-standing stifling definitions of identities which trap the individual in specific categories (Butler "Performative Acts" 278). In asserting that they are just "making art," The Wooster Group shows that "Art for Art's sake" can prove to be socially challenging since The Emperor Jones raises fundamental political questions.

\section{BIBLIOGRAPHY}

Auslander, Philip. Presence and Resistance: Postmodernism and Cultural Politics in Contemporary American Performance. Ann Arbor: U. of Michigan P., 1992.

Aberjhani, and Sandra L. West. Encyclopedia of the Harlem Renaissance. New York: Facts On File, Inc, 2003.

Balme B. Christopher. "Robert Lepage und die Zukunft des Theaters im Medienzeitaller.” In Maschinen, Medien, Performances: Theater an des Schmittstte zu Digital Welten. Ed. Martina Leeker. Berlin: Alexander Verlag, 2001. 668-683.

Barlow, Judith E. “O'Neill's Female Characters” in The Cambridge Companion to Eugene O'Neill. Manheim, Michael. Cambridge: Cambridge UP, 1998. 164-176.

Barthes, Roland. “The Death of the Author” Web site. (2000). 13 Nov. 2012. http:// www.tbook.constantvzw.org/wp-content/death_authorbarthes.pdf

Bechtel, Roger. "Brutus Jones 'n the 'Hood: The Provincetown Players, The Wooster Group, and the Theatrical History." In Past Performance. American Theatre and the Historical Imagination. Ed. Roger Bechtel. Lewisburg: Bucknell UP, 2007. 128-167.

Ben-Zvi, Linda. "Notes on the text." In The Road to the Temple. A Biography of George Cram Cook. Eds. Susan Glaspell and Linda Ben-Zvi. Jefferson, N.C: McFarland, 2005. 1-18.

Butler, Judith. Bodies That Matter: On the Discursive Limits of “Sex.” New York: Routledge, 2011. Butler, Judith. Gender Trouble: Feminism and the Subversion of Identity. New York: Routledge, 2006. Butler, Judith. "Performative Acts and Gender Constitution: An Essay in Phenomenology and Feminist Theory." In Performing Feminisms: Feminist Critical Theory and Theatre. Ed. Sue-Ellen Case. Baltimore: Johns Hopkins UP, 1990. 270-282.

Diggins, John P. Eugene O'Neill's America: Desire Under Democracy. Chicago: U. of Chicago P., 2007. Dowling, Robert M. Critical Companion to Eugene O'Neill: A Literary Reference to His Life and Work. New York, NY: Facts on File, 2009.

Du Bois, W.E.B. “Negro Art” (1926). Du Bois on Reform. Ed. Brian Johnson. Lanham: Alta Mira P., 2005. 227-230.

Du Bois, W.E.B. “The Negro and the American Stage.” The Crisis 28 (June 1924): 55-9.

Dymkowski, Christine. “Bibliographical Sketch of O’Neill.” In Anna Christie \& the Emperor Jones. Eugene O'Neill. London: Royal National Theatre/Nick Hern, 2005. 
Frank, Glanda. "Review of The Emperor Jones. The First Floor Theatre; The Emperor Jones. The Wooster Group." Eugene O’Neill.Com. [archived: https://web.archive.org/web/20131215110302/ http://www.eoneill.com/reviews/jones_frank.htm]

Garber, Marjorie B. Vested Interests: Cross-dressing \& Cultural Anxiety. New York: Routledge, 1992. Gassner, John, and Edward Quinn. The Reader's Encyclopedia of World Drama. New York: Crowell, 1969.

Greenwald, Michael L., Roger Schultz, and Roberto Darío Pomo. The Longman Anthology of Drama and Theater: A Global Perspective. New York: Longman, 2002.

Innes, Christopher. Avant Garde Theatre, 1892-1992. London: Routledge, 1993.

Jouve, Emeline. “Through the Looking Glass. The Wooster Group's The Emperor Jones (1993, 2006, 2009): Representation and Transgression." Revista de Estudios Norteamericanos 17 (2013): 61-80. https://revistascientificas.us.es/index.php/ESTUDIOS_NORTEAMERICANOS/article/view/4650. DOI: $10.12795 /$ REN

Kenton, Edna. The Provincetown Players and the Playwrights' Theatre, 1915-1922 (Ts. 1930s). Eds. Travis Bogard and Jackson R. Bryer. Jefferson: McFarland \& Company, 2004.

Krasner, David. A Beautiful Pageant: African American Theatre, Drama, and Performance in the Harlem Renaissance, 1910-1927. New York: Palgrave Macmillan, 2002.

King, W D. “Introduction." A Wind Is Rising: The Correspondence of Agnes Boulton and Eugene O'Neill. Agnes Boulton and Eugene O’Neill. Madison: Fairleigh Dickinson UP, 2000. 9-30.

Le Bastard, Gwenola. “Censorship, Control and Resistance in Eugene O'Neill's 'black plays' The Emperor Jones and All God's Chillun Got Wings". Revue LISA/LISA e-journal XI.3 (2013). DOI: 10.4000/ lisa.5519

Lehmann, Hans-Thies. Postdramatic Theatre. London: Routledge, 2006.

McArthur, Benjamin. Actors and American Culture, 1880-1920. Philadelphia: Temple UP, 1984.

Monks, Aoife. “'Genuine Negroes and Real Bloodhounds': Cross-Dressing, Eugene O’Neill, The Wooster Group, and the Emperor Jones." Modern Drama 48.3 (2005): 540-564. DOI: 10.1353/mdr. 2006.0013

O’Neill, Eugene. Emperor Jones. Sitwell: Digireads Com, 2009.

Pavis, Patrice. Dictionary of the Theatre: Terms, Concepts, and Analysis. Trans. Christine Shantz. Toronto: U. of Toronto P., 1998.

Pfister, Joel. Staging Depth: Eugene O'Neill and the Politics of Psychological Discourse. Chapel Hill: U. of North Carolina P., 1995.

Quick, Andrew. Wooster Group Book. London: Routledge, 2007.

Ranald, Margaret L. The Eugene O’Neill Companion. Westport, Conn: Greenwood P., 1984.

Salih, Sara. Judith Butler. London: Routledge, 2002.

Salzman, Jack, David L. Smith, and Cornel West (eds.). Encyclopedia of African-American Culture and History. New York: Macmillan Library Reference, 1996.

Sarlós, Robert K. Jig Cook and the Provincetown Players: Theatre in Ferment. Amherst: U. of Massachusetts P., 1982.

Savran, David. Breaking the Rules. New York: Theatre Communications Group, 1991. 
Savran, David. "Obeying the Rules." The Wooster Group and Its Traditions. Ed. Johan Callens.

Brussels: P.I.E.-Peter Lang, 2004. 63-70.

Schechner, Richard. Environmental Theater. New York: Applause, 1994.

Shafer, Yvonnes. Eugene O'Neill and American Society. Valencia: Universitat de Valencia P., 2011.

Shaughnessy, Edward L. “O’Neill's African and Irish-Americans: stereotypes or 'faithful realism'?” The Cambridge Companion to Eugene O'Neill. Ed. Michael Manheim. Cambridge: Cambridge UP, 1998. 148-163.

Sheaffer, Louis. O'Neill, Son and Artist. Boston: Little, Brown, 1973.

Smith, Cherise. Enacting Others: Politics of Identity in Eleanor Antin, Nikki S. Lee, Adrian Piper, and Anna Deavere Smith. Durham, NC: Duke UP, 2011.

Smith, Eric L. Bert Williams: A Biography of the Pioneer Black Comedian. Jefferson, N.C: McFarland, 1992.

Styan, J. L. Modern Drama in Theory and Practice: Expressionism and Epic Theatre. Vol. 3. Cambridge: Cambridge UP, 1981.

The Wooster Group - Facebook, https://www.facebook.com/TheWoosterGroup/

Waugh, Patricia. Metafiction: The Theory and Practice of Self-Conscious Fiction. London: Methuen, 1984.

Wikander, Matthew H. "O'Neill and the Cult of Sincerity." The Cambridge Companion to Eugene O’Neill. Ed. Michael Manheim: Cambridge: Cambridge UP, 1998. 217-235.

Witham, Barry B. Sustainable Theatre: Jasper Deeter at Hedgerow. New York: Palgrave Macmillan, 2013.

\section{NOTES}

1. Judith Butler posits that there is an industry of racial construction, yet she remains very vague on the issue. Scholars, like E. Patrick Johnson among others, have however demonstrated that her theory of performativity is relevant to analyze race.

2. Due to its original success, the production of The Emperor Jones was revived in 2006 and again in 2009. The present analysis of The Wooster's staging of O'Neill's play is based on the DVD recording of the performance at the Goodman Theatre, Chicago, Illinois, on January 10th, 2009 during the O'Neill Festival.

3. In the 2009 Chicago production, Smithers was played by Ari Fliakos and the Stage Assistant by Scott Shepherd.

4. The comparison between drag and blackface is relevant from a formal, structural point of view in that they both consist in adopting a socially constructed preexisting model to signify this model. Politically, however, these two strategies of imitation strongly differ: blackfacing was initially performed in order to make fun and devalue black identity, whereas dragging was originally adopted as a form of protest and emancipation. As will be seen later in this paper, Butler denounces dragging as she believes that it paradoxically maintains the traditional dominant norms rather than subverting them as it is meant to do. The analogy between drag and black-face remains a touchy issue as shown by the recent controversy sparked by remarks uttered in January 2015 by Mary Cheney, the daughter of former US Vice-President Dick Cheney, in which she compared drag and blackface. 
5. "Performative Acts and Gender Constitution: An Essay in Phenomenology and Feminist Theory" was first published in 1988 in Theatre Journal, Vol. 4, No. 4. Butler's article was the object of an intense critical debate by feminist theatre scholars, such as Jill Dolan and Elin Diamond. In the November 1993 issue of GLQ: A Journal of Lesbian and Gay Studies, Butler published "Critically Queer" in which she discusses her initial assertions about theatre. As this article was written after The Wooster Group's original production, I will not discuss it here.

6. It could be argued that a show repeats itself night after night, but the term "repetition" is here to be understood as "imitation" of a preexisting discourse, whether it be a script or a social pattern, and not in the sense of "reiteration."

7. As I demonstrated in "Through the Looking-Glass," the strategies of distanciation used by The Wooster Group in The Emperor Jones are manifold. The company plays with masks to establish psychological distance but the alienation of the characters "was also conveyed by the use of different media on stage, attracting the audience's attention to the fabric of the show." Moreover, the company played with the spectators' expectations (Jouve).

8. Judith Butler does not make any distinction among the different theatrical genres and she posits distance between the fictive world and the "real" world as a principle underlying the art of theatre, a generalization that can be questioned.

9. In Environmental Theater, Richard Schechner emphasizes the importance of the audience's participation in the show which should be perceived as a "social event" and no longer a fiction: "Participation occurred at those points where the play stopped being a play and became a social event-when spectators felt that they were free to enter the performance as equals. At these times, the themes of the play-its 'literary values'-were advanced not textually but wholly through action [...] For spectators who participated, performers were no longer actors but people doing what they believed in 'spontaneously.' It was impossible for most people to acknowledge that the attributes of 'actor' and 'person' were not mutually exclusive [...] letting people into the play to do as the performers were doing, to "join the story." (44)

\section{ABSTRACTS}

This paper is a study of The Wooster Group's staging of identity-related tensions in Eugene O'Neill's The Emperor Jones. Using Judith Butler's theories on performativity as an analytical framework, this paper shows how Elizabeth LeCompte's iconoclastic American company deconstructs O'Neill's 1920 work to "trouble" the traditional configurations of both gender and race. By playing with the codes of representation, The Wooster Group sheds light on the artificiality of the conventional binary system opposing the masculine to the feminine and Whites to Blacks. As they subvert traditional signs and symbols, The Wooster Group creates an "aesthetic of resistance," this paper argues, opening onto a reconfiguration of gender and race identities.

Cet article s'intéresse à la façon dont le Wooster Group met en scène les problématiques liés à la construction d'identités genrées et raciales dans The Emperor Jones de Eugene O'Neill. Convoquant les théories de Judith Butler sur la performativité, cette étude démontre comment la compagnie américaine iconoclaste fondée par Elizabeth LeCompte déconstruit l'œuvre originale de 1920 pour venir semer le "trouble", selon l'expression de Butler dans Gender Trouble, dans les configurations traditionnelles des genres et de ce que les Américains définissent comme 
« races.» The Wooster Group met en avant le caractère artificiel des conventions sociales qui opposent le féminin au masculin, les blancs aux noirs, en subvertissant les codes de représentation. La compagnie se joue alors des signifiants et des symboles et crée une "esthétique de résistance» ouvrant des perspectives sur une possible reconfiguration des identités par-delà le système binaire normatif.

\section{INDEX}

Mots-clés: théâtre, théâtre américain, performance, performativité, genre, race, O'Neill Eugene, Wooster Group (The), Butler Judith

Keywords: theatre, American theatre, performance, performativity, gender, race, O'Neill Eugene, Wooster Group (The), Butler Judith

\section{AUTHOR}

\section{EMELINE JOUVE}

Emeline Jouve is Assistant Professor of American Literature and Culture at Champollion University and Toulouse Jean-Jaurès University (France). She is the chair of the English department at Champollion University. She has given papers at several international conferences in France, Spain, and the U.S.A. on Susan Glaspell, Eugene O'Neill, Gertrude Stein, Paula Vogel, the Wooster Group and the Big Art Group and has published articles in French and American journals and anthologies. She edited the issue on "Staging Mobility in the United States" for the journal Miranda and co-edited the issue on "Staging American Memories" for the journal Les Cahiers de FRAMESPA (forthcoming). She also co-edited Susan Glaspell's Trifles and "A Jury of Her Peers": Centennial Essays, Interviews, and Adaptations with Martha C. Carpentier (McFarland; forthcoming). Emeline Jouve is the editor of the new section "Ariel's Corner: theatre" for the peer-reviewed e-journal Miranda. Apart from her academic work, Jouve is also involved in the practice of theatre, staging several plays and working with professional theatre companies. Contact: emeline.jouve [at] gmail.com 